\title{
Objective: Treatment by Illicium Verum and Turnip to Cure Cancer without Any Side Effect than Modern Medicine.
}

\author{
Rana Kausar ${ }^{1}$, Nazish Waris ${ }^{1}$, \\ Department of Biochemistry, Federal Urdu University, Karachi, Pakistan
}

\begin{abstract}
The present study was used to design to cure cancers by the treatment of Chinese star anise (illicium verum) extraction (not Japanese star anise) and vegetables (Leaf Turnip) in relation with vit.C antioxidant activity. Hepatotoxicity was produced by using Phenobarbital while vit.C analysis from star anise, leaf turnip, lemon juice, lemon peel and lemon pulp was done by iodometric titration method. It was observed that lemon and leaf turnip are mostly used in diet contain antioxidant activity while illicium verum was rarely used in diet contain more antioxidant activity as compare to others. Rats were given compound according to their body weight as $1 \mathrm{mg} / \mathrm{kg}$ b.w. After 21 days of treatment behavioral activity was monitored by locomotors activity in open field experiment, stimulatory activity in home cage and anxiolytic effects observed in light and dark apparatus and also in $T$ maze, were significantly increased in illicium verum and turnip treated rats. Hematological study including $\mathrm{Hb}, \mathrm{WBC}, \mathrm{RBC}, \mathrm{MCV}, \mathrm{MCH}, \mathrm{MCHC}, \mathrm{RDW}$ and Platelets was done by abbot laboratory analyzer cell. The value of $H b$ and $R B C$ was also significantly increased in star anise and turnip treated rats, showed proper function of RBC in microcirculation. WBC was also in normal range revealed that no disease regards to bone marrow and leukemias. The biochemical activity of rats including urea, creatinine, total protein, albumin, globulin, A/G ratio, amylase and calcium in blood serum were analyzed while, liver activity was also determined by LFT (liver function test). Behavioral and laboratorial variables were analyzed by using SPSS v. 20 and p-value $<0.05$ was considered statistically significant. Thus, the aim of the study is to enhance the function of star anise or illicium verum as an anticancer agent.
\end{abstract}

Keywords: Illicium verum; Turnip leaf; Hepatotoxicity; antioxidant; hematology; biochemical; LFT.

Highlights:

$>$ Herbal treatment is focused to treat cancer as compare to modern medicine to reduce the side effect.

> Illicium verum and turnip contain more antioxidant activity than lemon and can be used to cure cancers.

$>$ Hepatotoxicity is produced by using phenobarbital.

\section{Introduction}

Modern world running very fast to slow the harmful diseases which relate with living system but other side we see many diseases which not recover yet or we can't cease that diseases to treat public health. Liver cancer is one of them still alive to damage the human life and it is the second leading cause of cancer death. Liver cancer is the sixth most common cancer globally, calculating for 600,000 new cancer cases annually. The major burden of this disease lies in the developing countries. In Pakistan, 6 per 100,000 males can be affected and also 4 per 100,000 females. (1) Most of the patients present in their forties and fifties. It portages the overall survival rates of 3-5\% only. In 2012, it was occurred in 782,000 people and resulted in 746,000 deaths. (2) Past history have evidence that aromatic and medicinal plants are gift of nature are being used to treat several infections. (3) Thus, the ancient wisdom has been the basis of modern medicine and therapeutics. (4) Spice are important and essential in daily life. In these spice, Star Anise (Chinese star anise) also includes used as medicine due to its various effect. Don't confuse it with Japanese star anise, which is toxic and poisonous not for taken. Star anise (illicium verum) is a herb, considered a health curing medicine herb, and used to in relieving cold-stagnation (5). Cases of illness, including serious neurological effects, seizures, stomach issues, flu, viral infections and oxidative stress can be prevented by using Star anise. Previous study also indicated that Star anise also possess potent antimicrobial properties due to anethole present in the dried fruit (6). In the present study, Vit .C contain useful importance due to the natural antioxidant character (7-9). Studies in the 1970s and 1980s accompanied by Linus Pauling, Ewan Cameron, and colleagues suggested that very large doses of vitamin C (10 grams/day infused intravenously for 10 days followed by at least 10 grams/day orally indefinitely) were helpful in increasing the durability time and elaborating the quality of life of terminal cancer patients.(10) But, the anticancer mechanism of intravenous vitamin $\mathrm{C}$ reaction is under investigation. It may involve the production of high levels of hydrogen peroxide, selectively toxic to cancer cells $(11,12)$. Present study was used to design on illicium verum, vegetables (leaf turnip) and Phenobarbital Phenobarbital is the member of barbiturate family, used in curing many diseases like seizure $(13,14)$, but its side effect also worse like severe allergic reactions and swelling of different parts etc. So, in the current study, it 
was used as a carcinogenic agent. So, the new idea that was used in research, was use of illicium verum to cure cancer and compare it with vegetable (leaf turnip) and vit. $\mathrm{C}$ due to their antioxidant effects.

\section{Methodology}

The spice Illicium verum (Star anise) belongs to Schisandraceae orllliciaceae was collected from a market, store at airtight bottle away from sunlight, whole spice was powdered, which was then subjected using ethanol and saline $(0.9 \%)$ to form extraction. After 48 hours Ethanol and Saline extract filtered by filter paper to separate extract material. Six Eppendorf were filled by extract filtrate, saline extract filtrate into four Eppendorf and ethanol extract filtrate into two Eppendorf. Saline extract liquid used in Vit.C analysis and used on rat for antioxidant activity study. Few ethanol extract was also used in Vit.C analysis. Remaining ethanol extract and whole spice ethanol extract liquid used on rat for analyzing antioxidant activity.

\section{To determine the concentration of Vit.C for comparison in Lemon and Illicium verum by titrating Iodometric method.}

Vit.C was determined by titration method, which is a volumetric analysis. Squeeze fresh lemons to obtain lemon juice which is $40 \mathrm{ml}$. Take pulp cells from lemon endocarp, first weigh filter paper which is 812 $\mathrm{gm}$ and then weigh pulp cell three times into electronic weigh machine which is $195 \mathrm{gm}$. Prepare standard Vit.C solution $0.1 \mathrm{gm} / 500 \mathrm{ml}$ used as a control. Prepare starch $1 \%$ by dissolving $1 \mathrm{gm}$ starch into $100 \mathrm{ml}$ water then heat the solution till transparent color appear. Potassium iodide (KI) and Iodide solution prepared by dissolving $5 \mathrm{gm} \mathrm{KI}$ and $2.65 \mathrm{gm}$ Iodide into $1000 \mathrm{ml}$ water. Transfer $1 \mathrm{ml}$ Vit.C solution into flask, one drop of starch and 10 drops of $\mathrm{H}_{2} \mathrm{SO}_{4}$. Now, after washing burette, fill it with $\mathrm{KI}$ and Iodide solution. Titrate the solution till blue color not appear. Note down six readings of burette after titrating six times. Similarly, titrate pulp cell by putting $195 \mathrm{gm}$ pulp cell into $0.1 \mathrm{ml}$ water, one drop starch and 10 drops of $\mathrm{H}_{2} \mathrm{SO}_{4}$ in conical flask and also note down the six readings of burette. Titrate lemon peel by putting $86 \mathrm{gm}$ peel into $0.1 \mathrm{ml}$ water, one drop starch and 10 drops of $\mathrm{H}_{2} \mathrm{SO}_{4}$ in conical flask and also note down six readings of burette. Titrate by transferring $0.1 \mathrm{ml}$ Ethanol extract containing compound, one drop starch and 10 drops of $\mathrm{H}_{2} \mathrm{SO}_{4}$ in conical flask and note down the six readings of burette. Calculate the conc. of Vit.C by compairing results of control with sample of lemon and sample of compound.

\section{Phenobarbital induced hepatoxicity in rats:}

Hypersensitivity reaction leads to fever, rash, facial edema, lymphadenopathy, elevations in white count and eosinophilia, occurring in 1 week to several months after starting treatment with phenobarbital. Liver involvement is common but prolong treatment causes hepatic involvement is more prominent with elevations in serum enzyme levels, jaundice and even signs of hepatic failure.

\section{Experimental Protocol}

Study carried out by using 32 Albino wistar rats were purchased from Dow University and Hospital, Ojha campus, Karachi. They were housed individually in rat cage in animal house of Federal Urdu University Karachi with relatively food and water. Ethical clearance was obtained from Ethical committee of Federal Urdu University.The duration of study was 30 days. Rats were divided into four treated section, in each section 8 rats are included, which are as follows: I: Control group treated with saline as C. II: Test group, Phenobarbital (ZINOBI) drug as T1. III: Phenobarbital (ZINOBI) + Saline extract containing compound (Illicum verum) as T2. IV: Phenobarbital (ZINOBI) + Vegetable (Leaf Turnip) as T3. Drug was given to all rats as $1 \mathrm{mg} / \mathrm{kg} \mathrm{b.w.}$ Because of separate body weight and time duration drug samples were prepared separately. It was also preferred that rats containing similar weight kept together in a same group. In 1 st section 150 gm control rats $(\mathrm{C}), 1 \mathrm{ml}$ saline received by rats orally for 21 days. In $2^{\text {nd }}$ section $130 \mathrm{gm}$ rats $(\mathrm{T} 1)$, Phenobarbital (ZINOBI) received by rats orally at a dose of $1 \mathrm{mg} / \mathrm{kg}$ b.w. for 15 days. In $3^{\text {rd }}$ section $110 \mathrm{gm}$ (T2), Phenobarbital (ZINOBI) + Saline extract containing compound (Illicium verum) received by rats orally at a dose of $1 \mathrm{mg} / \mathrm{kg}$ b.w for 21 days. In $4^{\text {th }}$ section $115 \mathrm{gm}$ (T3), Phenobarbital (ZINOBI) received by rats and green leaf turnip 1 bunch orally every day for 21 days. During treatment rats were weigh again after 13 days left, weight of rats was such that 4 rats of T2 were $150 \mathrm{gm}$ and 2 rats of T3 were $160 \mathrm{gm}$ which was increased from its previous weight so, the dose was changed according to their body weight. After receiving doses by rats, behavioral activity was performed by instrument analysis.

Activity was monitored after injection for a week, for ten minutes, in light and dark environment. Light and dark activity is specific for anxiety the apparatus used in light and dark experiment consisted of small square area $(26 \times 26 \times 26 \mathrm{~cm})$ with an access $(12 \times 12 \mathrm{~cm})$ walls of one compartment was transparent and other dark. For the next five minutes the activity was monitored in the open field, and the open field apparatus consists of a square area $(76 \times 76 \mathrm{~cm})$ with walls of $42 \mathrm{~cm}$ high. The floor divided by lines into 25 equal squares. Ten minutes in home cage specially designed made up of Perspex $(26 \times 26 \times 26 \mathrm{~cm})$ with saw dust covered floor 
was used for this purpose. Last ten minutes in Plus T maze shaped apparatus used for screening and research anxiogenic and anxiolytic drugs, which have two open and closed arm each have open tool and elevated 40$70 \mathrm{~cm}$ from the floor. Number of entries and time spent in open arm are the anxiolytic drugs effect. After monitoring these activities, the animals returned to their cages.Rats were decapitated after 21 days of injection. The blood was collected from neck wound in the EDTA tubes for hematology. All hematological test has done in abbot laboratory analyzer cell while, blood in the Yellow top gel tubes, centrifuges to collect plasma for biochemical analysis. Biochemical analysis was done with the help of kits in laboratory on HSP system by Merck company.

\section{Statistical Analysis}

Results were represented as mean, $\pm \mathrm{SD}(\mathrm{n}=8)$ significant difference by Tukey HSD and Duncan test $\mathrm{p}<0.05$ level from C, T1, T2 and T3 following one-way ANOVA.

\section{Results}

A total of 32 rats $(n=8)$ were studied. Comparisons were made between different groups of rats as per their treatment. All Results were represented in table and as well as in graph asmean, \pm S.D, significant difference by Tukey HSD and Duncan test $\mathrm{p}<0.05$, following one-way ANOVA.After iodometric titration results were found according to which Lemon Peel in $86 \mathrm{mg}$ Vit.C concentration was more than lemon juice and lemon pulp. After Lemon Peel, Lemon Juice in $20 \mathrm{ml}$ and Lemon Pulp in $195 \mathrm{mg}$ contain same conc. of Vit.C. It also revealed that $0.1 \mathrm{ml}$ of Ethanol + Compound contain less value as compared to $0.1 \mathrm{ml}$ Saline + Compound, values showed that Vit.C was more in Saline + Compound as compared to Ethanol + Compound. In the eye of result analysis determined that in $86 \mathrm{mg}$ of Lemon Peel conc. was equal to Saline + Compound in $0.1 \mathrm{ml}$.

Table 1: Comparison of mean values of Vit.C concentration of b/w different Samples:

\begin{tabular}{|l|l|l|l|l|l|l|l|}
\hline $\begin{array}{l}\text { Vit.C } \\
\text { concentratio } \\
\mathrm{n} \text { in different } \\
\text { samples }\end{array}$ & $\begin{array}{l}\text { Mean } \pm \text { S.D } \\
\text { Juice Lemon }\end{array}$ & $\begin{array}{l}\text { Mean } \pm \text { S.D } \\
\text { Pulp Lemon }\end{array}$ & $\begin{array}{l}\text { Mean } \pm \text { S.D } \\
\text { Pe Lemon } \\
\text { Peel }\end{array}$ & $\begin{array}{l}\text { Mean } \pm \text { S.D of } \\
\text { Compound } \\
(\text { E }+ \text { C) }\end{array}$ & $\begin{array}{l}\text { Mean } \pm \text { S.D of } \\
\text { Saline + Compound } \\
\text { S+C) }\end{array}$ & $\begin{array}{l}\text { f-value } \\
\text { p-value }\end{array}$ \\
\hline & $0.02 \pm 1.481$ & $0.002 \pm 1.481$ & $0.04 \pm 1.50$ & $0.02 \pm 1.481$ & $0.04 \pm 1.505$ & 3.600 & $\mathrm{p}<0.046^{*}$ \\
\hline
\end{tabular}

* show result is significant

Table 2: Comparison of mean values ofBehavioural results in Control (C), T1, T2 and T3:

\begin{tabular}{|l|l|l|l|l|l|l|}
\hline Behavioral activity & $\begin{array}{l}\text { Mean } \pm \text { S.D } \\
\text { of control }\end{array}$ & $\begin{array}{l}\text { Mean } \pm \text { S.D } \\
\text { value of T1 }\end{array}$ & $\begin{array}{l}\text { Mean } \pm \text { S. D } \\
\text { value of T2 }\end{array}$ & $\begin{array}{l}\text { Mean } \pm \text { S.D } \\
\text { value of T3 }\end{array}$ & f- value & p-value \\
\hline Light and dark (no. of entries) & $2 \pm 0.89$ & $3.6 \pm 1.03$ & $5.7 \pm 1.98$ & $3.6 \pm 1.03$ & 26.825 & $\mathrm{p}<0.0001^{*}$ \\
\hline $\begin{array}{l}\text { Light and dark (time in } \\
\text { seconds) }\end{array}$ & $16.2 \pm 3.03$ & $59.7 \pm 5.12$ & $66.47 \pm 5.80$ & $38.7 \pm 4.03$ & 205434.508 & $\mathrm{p}<0.03^{*}$ \\
\hline $\begin{array}{l}\text { Home cage activity (walk in } \\
\text { seconds) }\end{array}$ & $4.5 \pm 1.58$ & $38.6 \pm 4.03$ & $51.9 \pm 4.99$ & $69.4 \pm 5.63$ & 248369.333 & $\mathrm{p}<0.0002^{*}$ \\
\hline $\begin{array}{l}\text { Home cage activity } \\
\text { (movement of head in sec.) }\end{array}$ & $0.7 \pm 0.001$ & $5.8 \pm 1.99$ & $0.1 \pm 0.00$ & $17 \pm 3.09$ & 721.176 & $\mathrm{p}<0.0001^{*}$ \\
\hline $\begin{array}{l}\text { Home cage activity (Climbing } \\
\text { in sec) }\end{array}$ & $0.2 \pm 0.00$ & $5.4 \pm 1.89$ & $13.1 \pm 2.69$ & $10.3 \pm 1.88$ & 9665.000 & $\mathrm{p}<0.0001^{*}$ \\
\hline $\begin{array}{l}\text { Open field activity (no of } \\
\text { square crossing) }\end{array}$ & $10.6 \pm 2.03$ & $23.3 \pm 3.89$ & $71.9 \pm 5.78$ & $82.4 \pm 5.99$ & 501308.000 & $\mathrm{p}<0.0001^{*}$ \\
\hline $\begin{array}{l}\text { Plus, T maize activity (entries } \\
\text { in open arms) }\end{array}$ & $2 \pm 0.89$ & $1.77 \pm 0.21$ & $3.06 \pm 1.00$ & $2.46 \pm 0.99$ & 3.887 & $\mathrm{p}<0.0001^{*}$ \\
\hline $\begin{array}{l}\text { Plus, T maize activity (time } \\
\text { spent in open arm in sec) }\end{array}$ & $242.8 \pm 11.87$ & $40.3 \pm 4.20$ & $50.03 \pm 4.63$ & $54.6 \pm 5.01$ & 3784246.203 & $\mathrm{p}<0.021^{*}$ \\
\hline
\end{tabular}

* show result is significant

Table 3: Comparison of mean values of Hematological results in Control (C), T1, T2 and T3:

\begin{tabular}{|l|l|l|l|l|l|l|}
\hline $\begin{array}{l}\text { Hematological parameter } \\
\text { result }\end{array}$ & $\begin{array}{l}\text { Mean } \pm \text { S.D } \\
\text { of control }\end{array}$ & $\begin{array}{l}\text { Mean } \pm \text { S.D } \\
\text { value of T1 }\end{array}$ & $\begin{array}{l}\text { Mean } \pm \text { S.D } \\
\text { value of T2 }\end{array}$ & $\begin{array}{l}\text { Mean } \pm \text { S.D } \\
\text { value of T3 }\end{array}$ & f-value \\
\hline Hemoglobin (Hb) & $7.7 \pm 1.86$ & $9.6 \pm 1.99$ & $10.8 \pm 2.04$ & $10.6 \pm 2.03$ & 462.000 & $\mathrm{p}<0.0001^{*}$ \\
\hline White blood cells (WBC) & $4.1 \pm 1.03$ & $7.7 \pm 1.86$ & $5.1 \pm 1.72$ & $9.1 \pm 1.92$ & 3075.960 & $\mathrm{p}<0.045^{*}$ \\
\hline $\begin{array}{l}\text { Red Cell Distribution Width } \\
\text { (RDW) }\end{array}$ & $12.1 \pm 2.14$ & $15.7 \pm 2.28$ & $16.6 \pm 2.29$ & $18 \pm 2.32$ & 2534.333 & $\mathrm{p}<0.002^{*}$ \\
\hline Platelets corpuscular volume & $155 \pm 6.10$ & $409 \pm 8.24$ & $535 \pm 8.99$ & $535 \pm 8.99$ & 96267.000 & $\mathrm{p}<0.036^{*}$ \\
\hline $\begin{array}{l}\text { Mean con } \\
\text { (MCV) }\end{array}$ & $72 \pm 5.78$ & $46 \pm 4.01$ & $46 \pm 4.01$ & $46 \pm 4.01$ & 507.000 & $\mathrm{p}<0.001^{*}$ \\
\hline $\begin{array}{l}\text { Mean corpuscular } \\
\text { hemoglobin (MCH) }\end{array}$ & $21 \pm 2.98$ & $22 \pm 2.99$ & $18.6 \pm 2.23$ & $17 \pm 2.39$ & 20.558 & $\mathrm{p}<0.021^{*}$ \\
\hline Mean corpuscular & & & & & \\
\hline
\end{tabular}


Objective: Treatment By Illicium Verum And Turnip To Cure Cancer Without Any Side Effect...

\begin{tabular}{|l|l|l|l|l|l|l|}
\hline $\begin{array}{l}\text { hemoglobin concentration } \\
\text { (MCHC) }\end{array}$ & $25 \pm 3.01$ & $46 \pm 3.98$ & $40 \pm 3.91$ & $36.9 \pm 2.98$ & 312.012 & $\mathrm{p}<0.0001^{*}$ \\
\hline red blood cell (RBC) & $2.94 \pm 0.02$ & $4.34 \pm 0.89$ & $6.25 \pm 1.18$ & $5.79 \pm 1.81$ & 9771.915 & $\mathrm{p}<0.004^{*}$ \\
\hline
\end{tabular}

* show result is significant

Table 4: Comparison of mean values of Biochemical results in Control (C), T1, T2 and T3:

\begin{tabular}{|c|c|c|c|c|c|c|}
\hline $\begin{array}{l}\text { Biochemical } \\
\text { parameter result }\end{array}$ & $\begin{array}{l}\text { Mean } \pm \text { S.D } \\
\text { of control }\end{array}$ & $\begin{array}{l}\text { Mean } \pm \text { S.D } \\
\text { value of } \mathrm{T} 1\end{array}$ & $\begin{array}{l}\text { Mean } \pm \text { S.D } \\
\text { value of T2 }\end{array}$ & $\begin{array}{l}\text { Mean } \pm \text { S.D value } \\
\text { of T3 }\end{array}$ & f- value & p-value \\
\hline Urea $(\mathrm{mg} / \mathrm{dl})$ & $24 \pm 2.59$ & $29 \pm 2.78$ & $28 \pm 2.76$ & $27 \pm 2.75$ & 462.000 & $\mathrm{p}<0.003^{*}$ \\
\hline Creatinine & $0.48 \pm 0.09$ & $0.6 \pm 0.001$ & $0.16 \pm 0.02$ & $0.11 \pm 0.04$ & 075.960 & $\mathrm{p}<0.0001$ \\
\hline Total Protein (mg/dl) & $6.21 \pm 0.89$ & $7.1 \pm 1.80$ & $3.2 \pm 1.13$ & $3.2 \pm 1.13$ & 2534.333 & $\mathrm{p}<0.0001$ \\
\hline Albumin (mg/dl) & $4.2 \pm 1.67$ & $4.0 \pm 1.60$ & $2.86 \pm 0.99$ & $2.86 \pm 0.97$ & 96267.000 & $\mathrm{p}<0.0002$ \\
\hline Globulin (mg/dl) & $2.01 \pm 0.78$ & $3.0 \pm 1.01$ & $0.34 \pm 0.08$ & $0.34 \pm 0.08$ & 507.000 & $\mathrm{p}<0.0001^{*}$ \\
\hline $\mathrm{A} / \mathrm{G}$ ratio & $2.09 \pm 0.89$ & $1.3 \pm 1.01$ & $8.41 \pm 1.99$ & $8.41 \pm 1.99$ & 20.558 & $\mathrm{p}<0.0001^{*}$ \\
\hline Amylase (U/1) & $1972 \pm 18.97$ & $1750 \pm 17.85$ & $1629 \pm 17.01$ & $1620 \pm 17.00$ & 312.012 & $\mathrm{p}<0.0001$ \\
\hline Calcium (mg/dl) & $9.1 \pm 1.87$ & $5.5 \pm 1.11$ & $6.85 \pm 1.53$ & $6.89 \pm 1.59$ & 9771.915 & $\mathrm{p}<0.0001$ \\
\hline
\end{tabular}

* show result is significant

Table 5: Comparison of mean values of Liver function test in Control (C), T1, T2 and T3:

\begin{tabular}{|l|l|l|l|l|l|l|}
\hline $\begin{array}{l}\text { Liver function test } \\
\text { Parameter }\end{array}$ & $\begin{array}{l}\text { Mean } \pm \text { S.D } \\
\text { of control }\end{array}$ & $\begin{array}{l}\text { Mean } \pm \\
\text { S.D value of T1 }\end{array}$ & $\begin{array}{l}\text { Mean } \mathbf{\pm S . D} \\
\text { value of T2 }\end{array}$ & $\begin{array}{l}\text { Mean } \mathbf{\pm S . D} \\
\text { value of T3 }\end{array}$ & f- value & p-value* \\
\hline $\begin{array}{l}\text { Total bilirubin in } \\
\text { (mg/ dl) }\end{array}$ & $0.35 \pm 0.12$ & $0.3 \pm 0.06$ & $0.25 \pm 0.10$ & $0.25 \pm 0.10$ & 68.750 & $\mathrm{p}<0.0003^{*}$ \\
\hline $\begin{array}{l}\text { Direct bilirubin in } \\
\text { (mg/dl) }\end{array}$ & $0.2 \pm 0.00$ & $0.1 \pm 0.00$ & $0.05 \pm 0.00$ & $0.05 \pm 0.00$ & 300 & $\mathrm{p}<0.002^{*}$ \\
\hline SGPT in U/L & $18 \pm 3.10$ & $80 \pm 6.23$ & $73 \pm 5.31$ & $70 \pm 5.29$ & 2432.750 & $\mathrm{p}<0.002$ \\
\hline SGOT in U/L & $36 \pm 4.10$ & $233 \pm 8.13$ & $213 \pm 7.98$ & $200 \pm 7.20$ & 18473.562 & $\mathrm{p}<0.0003^{*}$ \\
\hline Gamma GT in U/L & $30 \pm 3.98$ & $10 \pm 2.10$ & $2 \pm 0.33$ & $4 \pm 0.56$ & 491.000 & $\mathrm{p}<0.0001^{*}$ \\
\hline $\begin{array}{l}\text { Alkaline phosphate } \\
\text { in U/L }\end{array}$ & $120 \pm 7.34$ & $537 \pm 9.56$ & $115 \pm 6.25$ & $117 \pm 6.35$ & 132102.75 & $\mathrm{p}<0.025^{*}$ \\
\hline
\end{tabular}

* show result is significant.

\section{Graphs:}

Fig 1: Comparison of mean values of Vit.C concentration of b/w different Samples:

\section{Vit.C concentration of Samples}

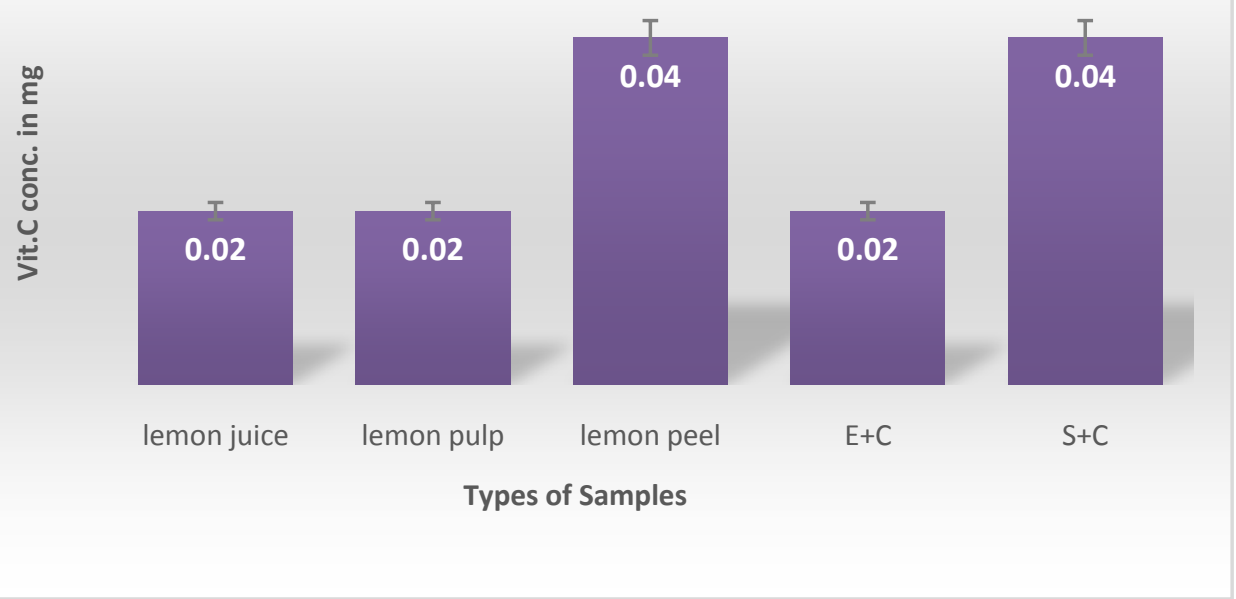

(a)

Fig 1: Results were represented as mean, \pm SD, significant difference by Tukey HSD and Duncan test $p<0.05$, following one-way ANOVA. (a) Vit.C concentration of Samples. 
Fig 2. Comparison of mean values of Hematological results in Control (C), T1, T2 and T3:

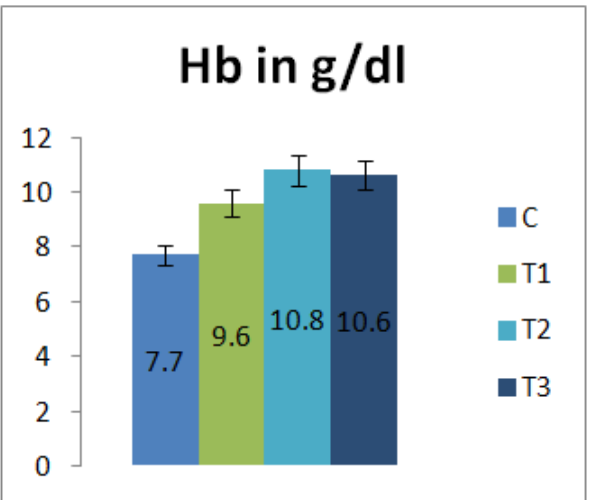

(a)

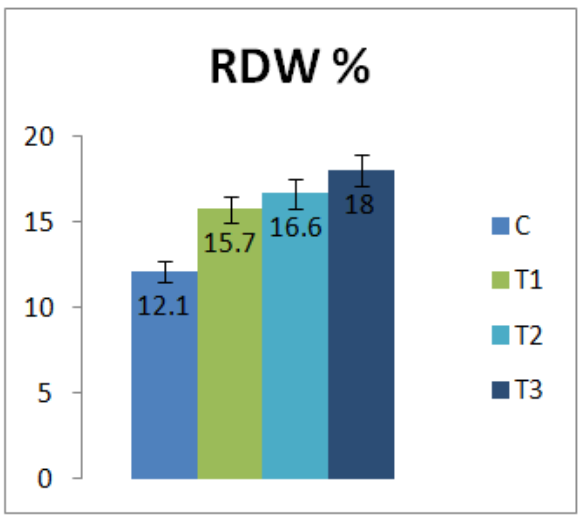

(c)

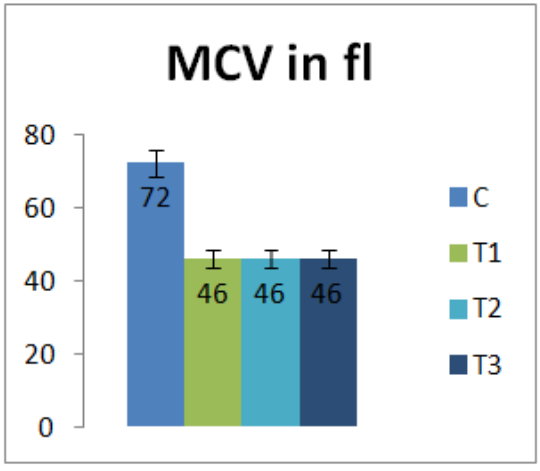

(e)

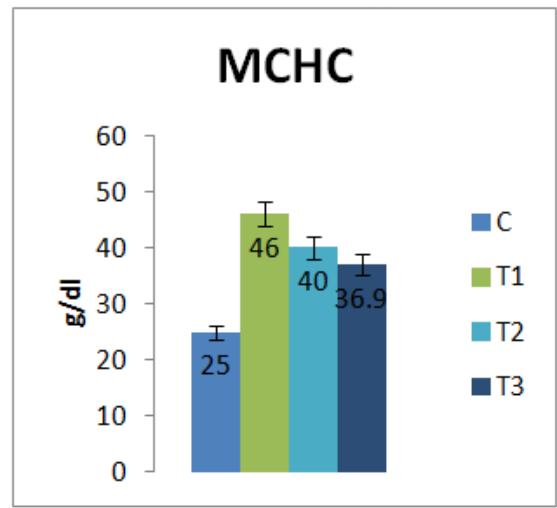

(g)

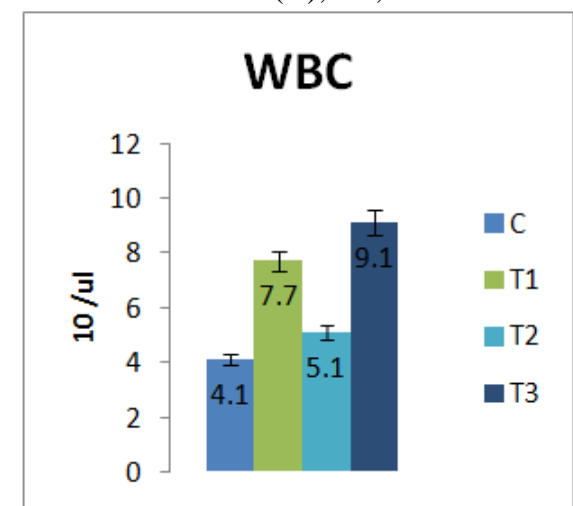

(b)

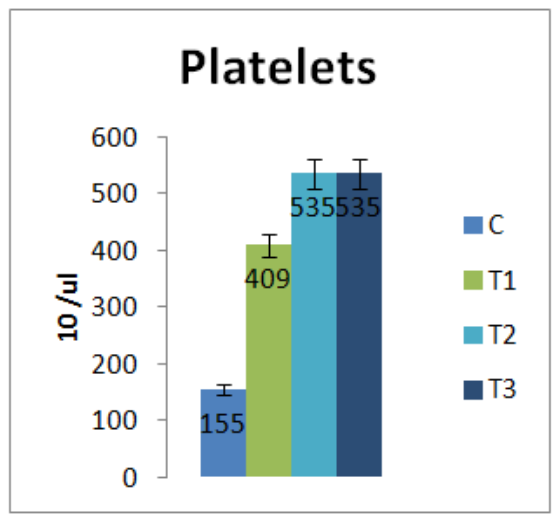

(d)

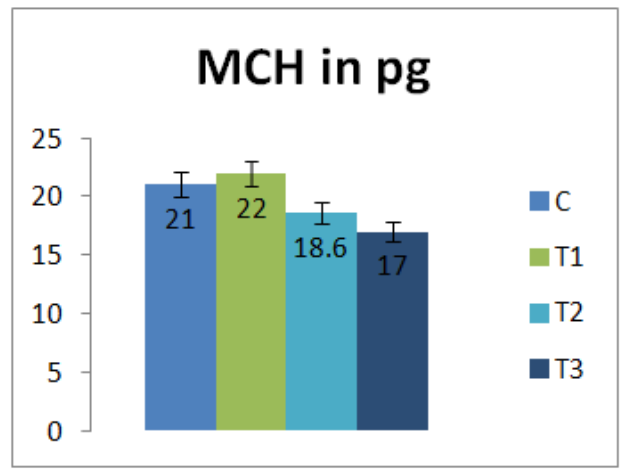

(f)

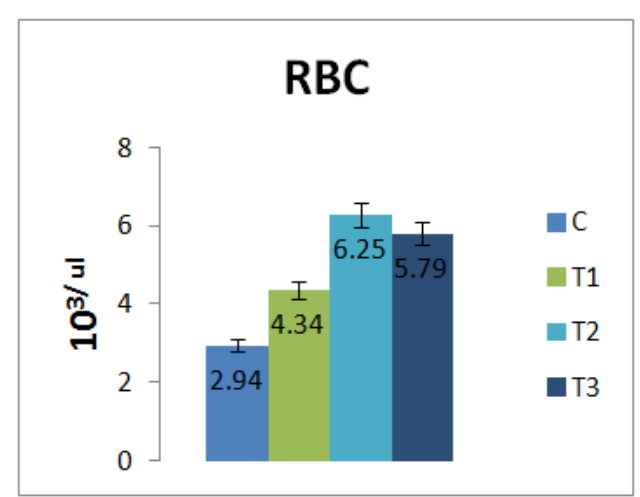

(h)

Fig 2: Results were represented as mean, \pm SD $(n=8)$ significant difference by Tukey HSD and Duncan test $\mathrm{p}<0.05$ level from C, T1, T2 and T3 following one-way ANOVA. (a) Hemoglobin in g/ dl (b) WBC in $10^{3} / \mathrm{ul}$ (c) RDW in \% (d) Platelets in $10^{3} / \mathrm{ul}$ (e) MCV in fl (f) MCH in pg. (g) MCHC in g/dl. (h) RBC in $10^{3} / \mathrm{ul}$. 
Fig 3. Comparison of mean values of Biochemical results in Control (C), T1, T2 and T3:

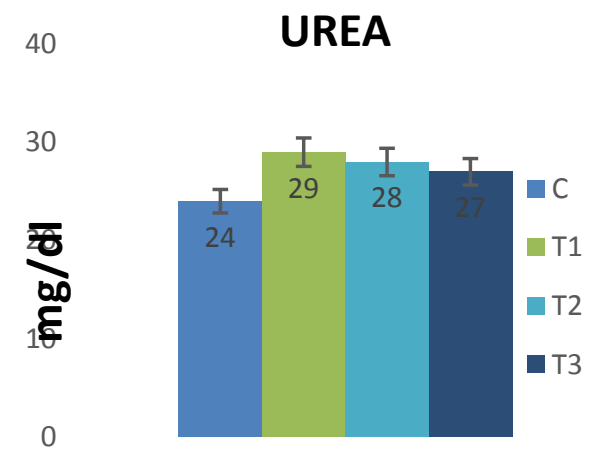

(a)

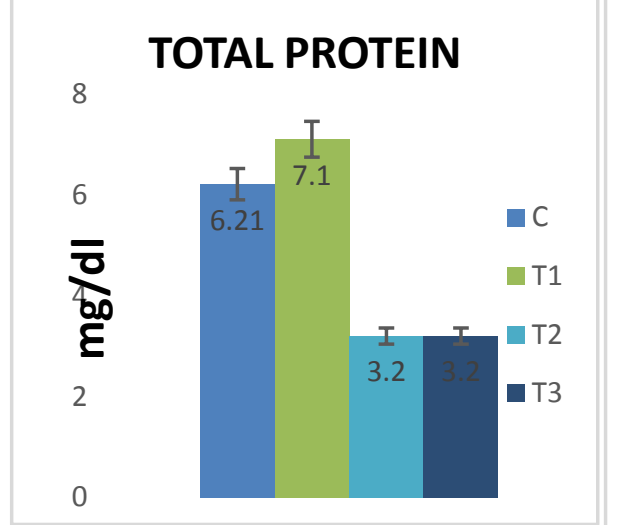

(c)

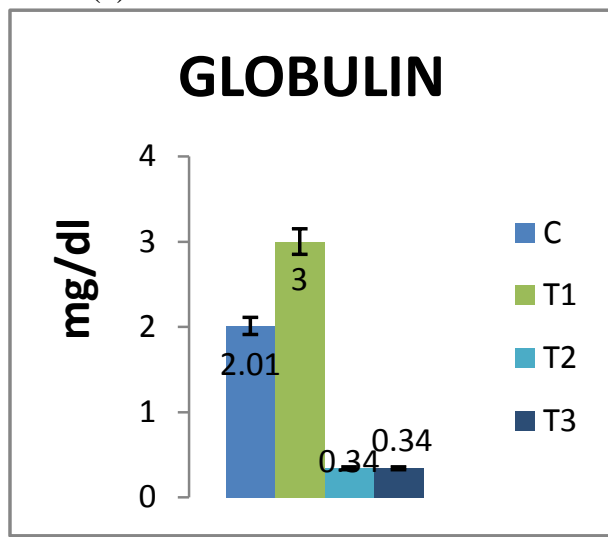

(e)

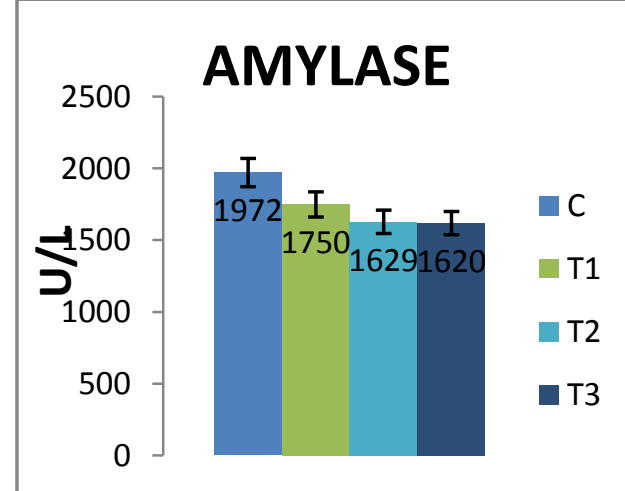

(g)

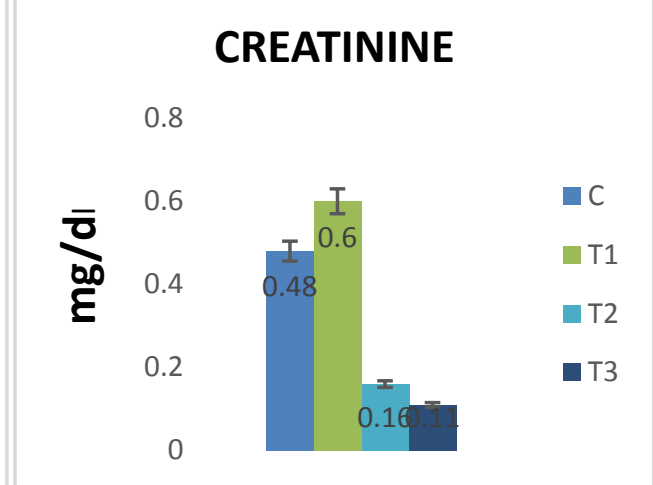

(b)

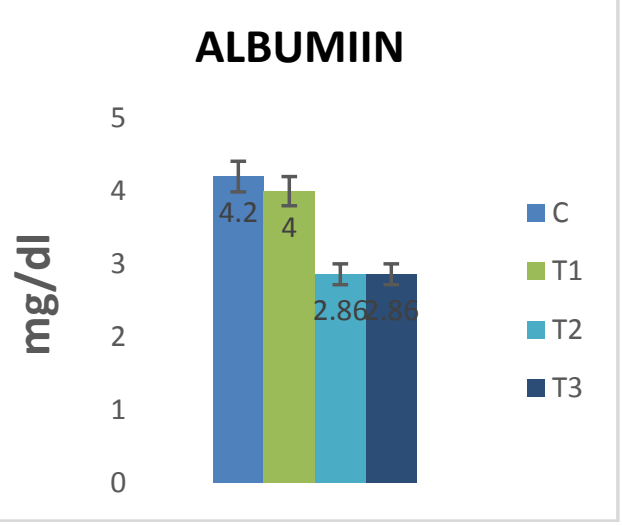

(d)

\section{A/G RATIO}

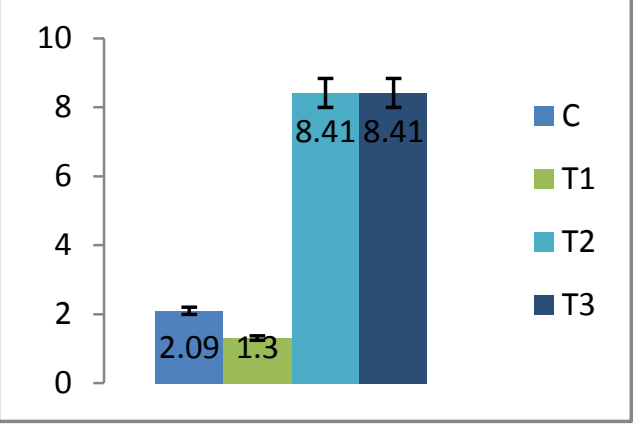

(f)

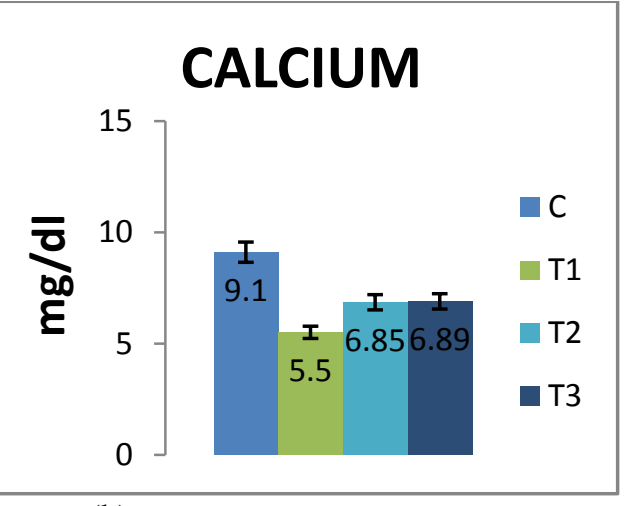

(h)

Fig 3: Results were represented as mean, \pm SD $(n=8)$ significant difference by Tukey HSD and Duncan test $p<0.05$ level from C, T1, T2 and T3 following one-way ANOVA. (a) Urea in mg/ dl (b) creatinine in mg/dl (c) Total protein in $\mathrm{mg} / \mathrm{dl}$ (d) Albumin in $\mathrm{mg} / \mathrm{dl}$ (e) Globulin in $\mathrm{mg} / \mathrm{dl}$ (f) A/G ratio (g)Amylase in $\mathrm{u} / \mathrm{l}$ (h) Calcium in g/dl. 
Fig 4: Comparison of mean values of Liver function test in Control (C), T1, T2 and T3:

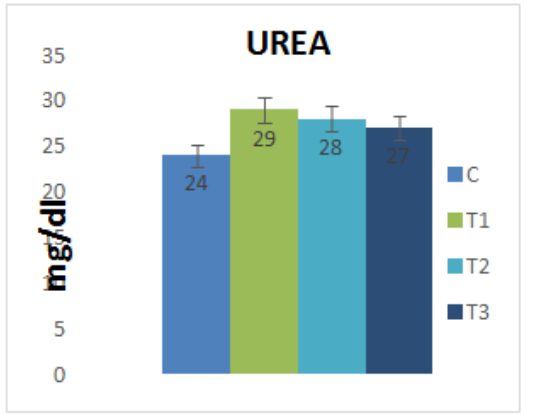

(a)

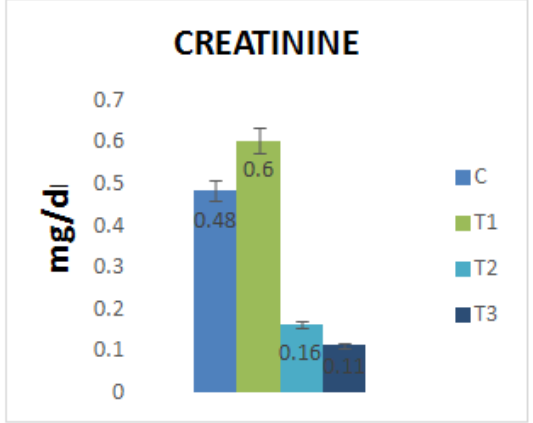

(b)

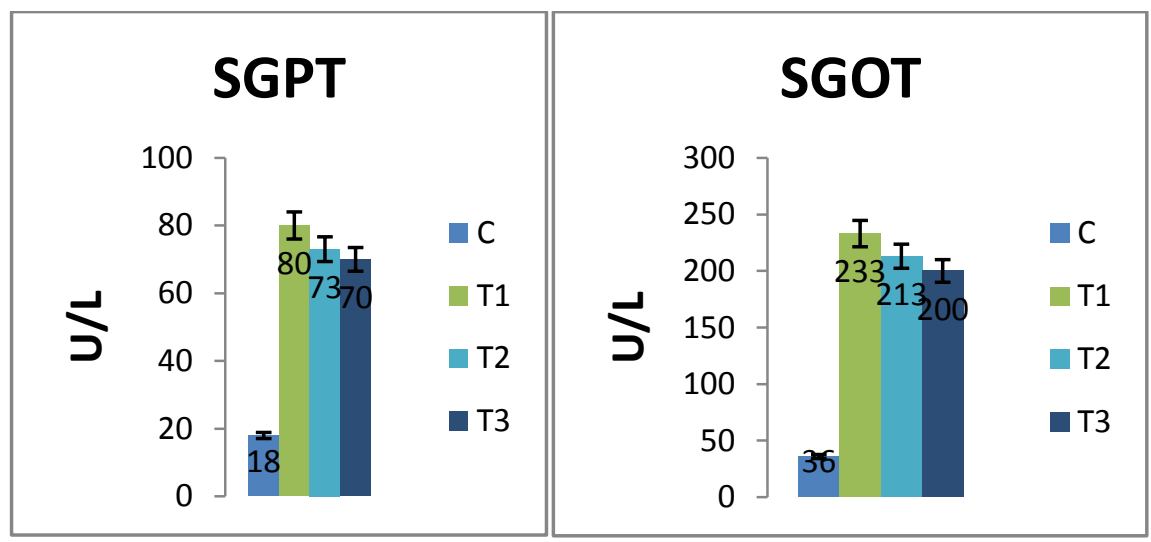

(c)

(d)

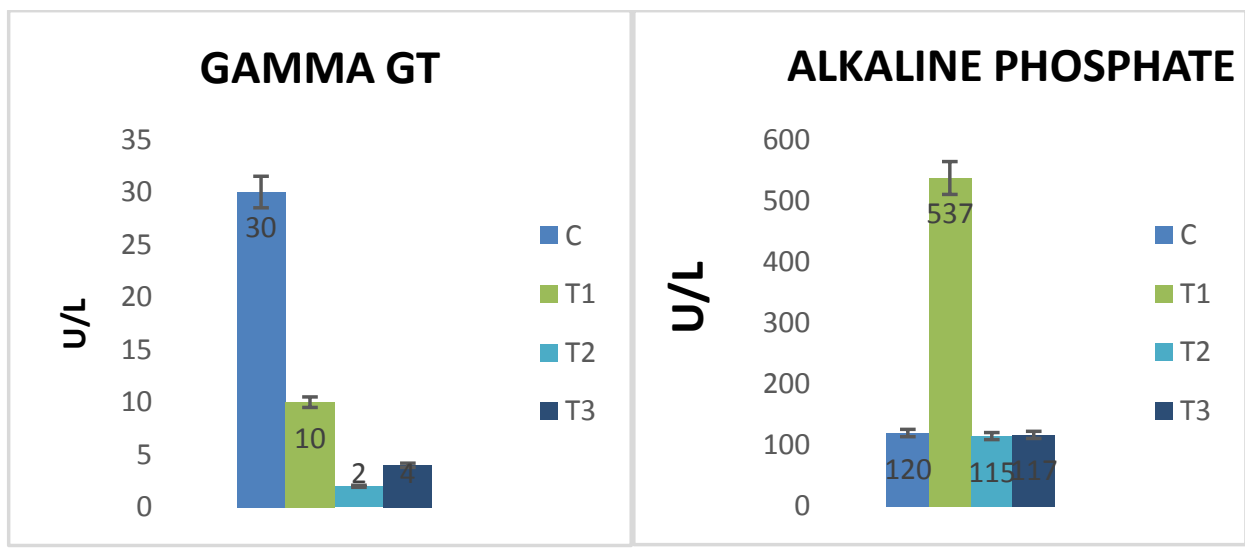

(e)

(f)

Fig 4: Results were represented as mean, $\pm \mathrm{SD}(\mathrm{n}=8)$ significant difference by Tukey HSD and Duncan test $\mathrm{p}<0.05$ level from C, T1, T2 and T3 following one-way ANOVA. (a) Total bilirubin in mg/ dl (b) Direct bilirubin in mg/dl (c) SGPT in U/L (d) SGOT in U/L (e) Gamma GT in U/L (f) Alkaline phosphate in U/L.

\section{Discussions}

Previously, many observational studies, including case-control studies and cohort studies, have been conducted to investigate whether the use of dietary antioxidant supplements were associated with reduced risks of cancer in humans. Overall, these studies have yielded mixed results (15). Because observational studies could not adequately have controlled for biases that might influence study outcomes, the results of any individual observational study must be viewed with caution. Vitamin $\mathrm{C}$ was determined by iodometric method in lemon and sample which showed the antioxidant activity of sample. Here, in the current study, the value of sample illicium verum and turnip leaf by titration was assessed, which showed higher antioxidant activity in the natural occurring compound help in reduction of oxidation in the body. Lemon Peel and Saline extraction of Illicium verum gave high antioxidant activity more than other samples. Reason behind Illicium verum gave their best antioxidant result in when extracted in saline. The antioxidant activity was done in vivo and in vitro. So, prediction showed that saline extraction produces more effect on oxidation. Lemon have high antioxidant 
activity due to higher concentration of Vit.C, was one of the natural antioxidant. But, here result showed something new idea that different sample of lemon gave variety of antioxidant activity. Lemon juice and its Pulp contain less amount than Lemon peel reason behind that peel contain more oxidative reducing compounds. Lemon peel was used as a treatment of oxidative stress as like in this study, Illicium verum extraction in saline was also used. Lemon Peel in $86 \mathrm{mg}$ contain high antioxidant activity among lemon samples which means Vit.C concentration was more than lemon juice and lemon pulp. After Lemon Peel, Lemon Juice in 20ml and Lemon Pulp in $195 \mathrm{mg}$ contain same conc. of Vit.C which showed equal antioxidant activity in lemon samples but 0.1 $\mathrm{ml}$ of Ethanol + Compound contain less antioxidant activity as compare to $0.1 \mathrm{ml}$ Saline + Compound, values showed that Vit.C was more in Saline + Compound as compare to Ethanol + Compound. Also, 86 mg of Lemon Peel conc. was equal to Saline + Compound in $0.1 \mathrm{ml}$ which showed that samples contain same Vit.C concentration. Antioxidant activity was also same due to same conc. of Vit.C. Lemon Juice in 20ml, Lemon Pulp in $195 \mathrm{mg}$ and Ethanol + Compound in $0.1 \mathrm{ml}$ contain same concentration of Vit. C which revealed that antioxidant activity was also same in all of them but less than Lemon Peel and Saline + Compound sample.

Behavioral activities were not shown graphically. Cage box activity T1 declined showing decreased in stimulant activity. T2 in last week declined as compare to $2^{\text {nd }}$ week because in $2^{\text {nd }}$ week, disease not so much produced. No head movement means not increased in stimulant activity. Stimulant activity was enhanced in T3 due to enhanced in walking movement in T3. So, stimulant activity enhanced by turnip. Cage box activity was increased in turnip treated rat which showed that turnip increases stimulant activity as compare to illicium verum by increasing CNS activity. After that T2 was more stimulant which was the result of illicium verum treatment. Open field activity showed that turnip treated rat revealed motor activity increased by turnip as same as illicium verum treated rat. Motor activity was reduced in T1 due to Phenobarbital which reduces its motor activity at last diminished. T2 illicium verum treated rat increased motor activity and equal value to turnip treated rat $\mathrm{T} 3$.

T maze showed anxiolytic effect in illicium verum treated rat because time and entries in open arm was increased which decreases anxiety. T1 gave anxiogenic effect. T1 value declined in open arm due to anxiety produced in rat which stay rat into closed arm. Illicium verum treated anxiety which increases time spent and entries in open arm. Illicium verum and turnip treated rat gave anxiolytic effect in Light and Dark box spent more time in light as compare to dark while Phenobarbital treated rat spent more time in dark. But, illicium verum treated rat spent more time in light as compare to other means, it increases anxiolytic effect as compare to turnip. T1 declined because anxiety was produced. T2 cure anxiety therefore time spent and entry in light box increased and anxiety declined. T3 also gave effect on anxiety due to enhance light box entry but turnip was not more treated anxiety as compare to illicium verum. Illicium verum treatment showed highest cure anxiety rate.

Hematological study showed that $\mathrm{Hb}$ level was in limit but significantly increased in illicium verum treated rat, showed no suppression. WBC was in normal range revealed that no disease regards to bone marrow and leukemia. RDW and platelets were also significantly increased in T2 and T3 rats. The main function of platelets is to contribute to hemostasis. It stops the process bleeding at the site of interrupted endothelium. Thrombocytosis in T2 and T3 showed that Phenobarbital inflamed liver cells and iron deficiency occurred here because, MCH decreased in all rats. MCV declined caused microcytosis and MCV low value showed that oxygen took part in oxidation therefore iron deficiency anemia occurred. MCHC was normal due to Hb normal due to turnip and illicium verum effect. The value of RBC (polycythemia) was also significantly increased, showed the dehydration in $\mathrm{T} 2$ and $\mathrm{T} 3$ rats due to low oxygen level, also showed proper function of RBC in microcirculation.

Biochemical estimation reveal that amylase level increases was due to pancreatitis because, normally $75 \%$ amylase increase due to pancreatitis so drug Phenobarbital also cause pancreatitis. Increase alkaline level show the liver damage phenomenon. Turnip (T3) and illicium verum (T2) treated rat bring alkaline level in normal range. ALT increase show that liver cannot perform their function properly due to phenobarbital administration. Bilirubin in normal limit shows that no jaundice. SGOT level also shows injury to liver by drug administration but turnip (T3) and illicium verum (T2) treated rat bring the level in decline as compare to drug administration rat. Gama gt is in normal range in turnip and illicium verum treated rat but also in limit of drug Phenobarbital administration rat. GGT functions in the body as a transport molecule, helping to move other molecules around the body. It plays a significant role in helping the liver metabolize drugs and other toxins. (16) Decline protein level demonstrate the effect of Phenobarbital in T2 and T3. Albumin and Globulin disturbance reveal the fact that liver function disturb which decreases the formation of Albumin and Globulin in T2 and T3 which reveal the Phenobarbital effect on hepatic cells. Hypocalcemia in T1, T2 and T3 shows that Vitamin D control the calcium level due to liver injury vitamin D level decreases which cannot maintain the calcium level. But fall in $\mathrm{T} 1$ is due to Phenobarbital effect but not decline in other rats due to turnip and illicium verum effect. 


\section{Conclusion}

The current study was based on the fact that medicine for the treatment of cancer blocked all the function of the body which produces critical situations. Treatment of cancer not specific region without any side effect can be controlled by increasing antioxidant activity which are retarded to cancer patient due to excessive oxidation in the body. In the present study, illicium verum was used as compare to turnip leaves and lemon to cure cancer by increasing antioxidant activity because it contains antioxidant agent more than both. It was also seen that in normal diet illicium verum was rarely used but using in diet can produce the good effects. It also showed the better effect on behavioral, hematological and biochemical studies, as behavioral study was increased by locomotor activity, stimulatory activity and decreased anxiety as compare to control while, Hematological study was also significantly increased, show proper function of RBC in microcirculation. Biochemical test results and liver enzymes activity was also significantly increased in illicium verum and turnip treated rats. Also result concluded that illicium verum increases body weight so, eating more biryani increased more weight because rats gained weight when treated by illicium verum. That means, illicium verum and turnip leaves both are given at a time to cure cancer as soon as possible in better and best way.

\section{References}

[1]. Available at : Liver Cancer in Pakistan | PSSLDpssld.org.pk/general information/liver-cancer-in-pakistan/ reviewed on 26 April 2016.

[2]. World Cancer Report 2014. World Health Organization. 2014. pp. Chapter 1.1. ISBN 9283204298

[3]. Khalil, M.Y, Moustafa, A.A, Naguib, N.Y., 2007. World j.Agric.Sci.,3(4):451-457.

[4]. Available at: Drug Discovery and Development: Traditional Medicine and. https://books.google.com.pk/books?isbn=8189422294 Bhushan Patwardhan - 2007 - Medical reviewed on 23 April 2016.

[5]. "Spaghetti Bolognese". In Search of Perfection. BBC Two.

[6]. Padayatty SJ, Katz A, Wang Y, Eck P, Kwon O, Lee JH, Chen S, Corpe C, Dutta A, Dutta SK, Levine M (February 2003). "Vitamin C as an antioxidant: evaluation of its role in disease prevention". Jam,Coll,Nutr 22(1): 135.doi:10.1080/07315724.2003.10719272.PMID 12569111. Archived from the original on July 21, 2010.

[7]. Combs J, Gerald F. The Vitamins. 4 ed. Burlington: Elsevier Science; 2012.

[8]. Erdman JW, MacDonald I, Zeisel SH, International Life Sciences Institute. Present knowledge in nutrition. 10th ed. Ames, Iowa: International Life Sciences Institute; 2012.

[9]. Cameron E, Pauling L. Supplemental ascorbate in the supportive treatment of cancer: Prolongation of survival times in terminal human cancer. Proc Natl AcadSci U S A. 1976;73(10):3685-3689.

[10]. Levine M, Padayatty SJ, Espey MG. Vitamin C: a concentration-function approach yields pharmacology and therapeutic discoveries. AdvNutr. 2011;2(2):78-88. (PubMed)

[11]. Chen Q, Espey MG, Krishna MC, et al. Pharmacologic ascorbic acid concentrations selectively kill cancer cells: action as a prodrug to deliver hydrogen peroxide to tissues. Proc Natl AcadSci U S A. 2005;102(38):13604-13609. (PubMed)

[12]. Stevens, George M. Brenner, Craig W. (2013).Pharmacology (4th ed.). Philadelphia, PA: Elsevier/Saunders. p. 204. ISBN 978-14557-0278-7.

[13]. Engel, Jerome (2008). Epilepsy: a comprehensive textbook (2nd ed.). Philadelphia: Wolters Kluwer Health/Lippincott Williams \& Wilkins. p. 1431. ISBN 978-0-7817-5777-5.

[14]. Antimicrobial properties of star anise (Illicium verum Hook f). - NCBI www.ncbi.nlm.nih.gov/pubmed/11807977

[15]. Patterson RE, White E, Kristal AR, et al. Vitamin supplements and cancer risk: the epidemiologic evidence. Cancer Causes and Control 1997; 8(5):786-802. [PubMed Abstract]

[16]. Available at : Gamma-GlutamylTranspeptidase Test - Healthlinewww.healthline.com/health/gamma-glutamyl-transpeptidase. reviewed on 20 june 2016 